\title{
Pendampingan Keluarga Dan Perawatan Orang Dengan Gangguan Jiwa Bebas Pasung
}

\author{
Syaifurrahman Hidayat ${ }^{1}$, Elyk Dwi Mumpuningtias ${ }^{2}$ \\ ${ }^{1,2}$ Program Studi Ilmu Keperawatan, Fakultas Ilmu Kesehatan, Universitas Wiraraja \\ e-mail: elykdwi@wiraraja.ac.id
}

\begin{abstract}
Abstrak
Kesehatan Jiwa masih belum menjadi agenda prioritas, terutama di daerah pedesaan dan pedalaman. Keluarga yang memiliki anggota keluarga dengan gangguan jiwa merawatnya dengan cara melakukan pasung. Hal tersebut merupakan salah satu bentuk diskriminasi terhadap orang dengan gangguan jiwa. Pemasungan telah menjadi tradisi bagi orang dengan gangguan jiwa. Pentingnya dukungan dan pendamping dimulai dari keluarga untuk menekan angka kekambuhan dan mengembalikan keberfungsian sosialnya.Tujuan dari kegiatan pengabdian kepada masyarakat ini yaitu mencari solusi dari permasalahan tersebut dengan memberikan pemahaman keluarga bahwa peran keluarga sangat penting dalam penyembuhan orang dengan gangguan jiwa. Metode yang digunakan yaitu membentuk kader kesehatan jiwa sebagai upaya penanganan awal dan segera serta pendampingan kepada keluarga maupun klien gangguan jiwa dalam perawatan sehari-hari di rumah dan di masyarakat. jenis kegiatan ini berupa penyuluhan dan pelatihan dalam perawatan klien dan keluarga gangguan jiwa bebas pasung. Tempat atau lokasi kegiatan PKM dilaksanakan di RT 02/RW01 Dusun Nangnangan Desa Saronggi Kecamatan Saronggi, yang dilaksanakan pada bulan April-Juni 2017 dengan kelompok sasaran adalah lingkungan sekitar warga.Keseluruhan rangkaian kegiatan mendapatkan respon balik dari peserta sehingga pengetahuan peserta tentang penanganan awal gejala pasien gangguan jiwa dapat diaplikasikan dan terbentuk Kader Kesehatan Jiwa oleh Tim PKM Unija di RT 02/RW01 Dusun Nangnangan Desa Saronggi Kecamatan Saronggi. Sosialisasi dan pendampingan pelayanan kesehatan jiwa dilakukan dengan kunjungan rumah oleh Tim PKM UNIJA dengan kader Keswa serta melakukan sosialisasi cara penanganan pasien dengan pasung.
\end{abstract}

Kata Kunci: Gangguan jiwa; bebas pasung

\begin{abstract}
Mental Health is still not a priority agenda, especially in rural and inland areas. Families who have family members with mental disorders care for them by doing" pasung". This is one form of discrimination against people with mental disorders. "Pasung" has become a tradition for people with mental disorders. The importance of support and companion begins with the family to reduce the number of relapses and restore their social functioning.The purpose of this activity was to find a solution to these problems by providing a family understanding that the role of the family is very important in healing people with mental disorders. The method used was to form a mental health worker as an effort to treat early and immediate as well as mentoring family and mental disorders clients in daily care at home and in the community. This type of activity were counseling and training in the care of clients and families of pasung-free mental disorders. The whole series of activities received feedback from the participants so that the participants' knowledge about the initial handling of the symptoms of mental illness patients could be applied and a Mental Health Cadre was formed by Uni PKM Tin in RT 02 / RW01 Nangnangan Hamlet, Saronggi Village, Saronggi District. The socialization and mentoring of mental health services was carried out by visiting the house by the PKM UNIJA Team with Keswa as a health worker and conducting socialization on how to handle patients with pasung.
\end{abstract}

Keywords: mental disorder; pasung 


\section{PENDAhuluan}

Gangguan jiwa masih menjadi trend dan isu kesehatan mental yang memerlukan perhatian dari pemerintah ataupun pihak terkait kesehatan mental. Mengacu pada data World Health Organization, kurang lebih 450 juta orang di dunia mengalami gangguan pada kesehatan mental. Data dari WHO menunjukkan $0,25 \%$ orang di dunia menderita masalah mental dan menyebutkan bahwa gangguan jiwa merupakan masalah yang serius. Menurut National Institute Of Mental Health gangguan jiwa menyentuh angka $13 \%$ dari keseluruhan penyakit dan akan meningkat mencapai $25 \%$ pada tahun 2030. Maka akan menyebabkan peningkatan persentase gangguan jiwa di berbagai negara ${ }^{1}$.Hasil Riskesdas tahun 2007 dan 2013 menunjukkan bahwa persentase gangguan jiwa berat di Indonesia masing-masing sebesar 4,6 per mil dan 1,7 per mil ${ }^{2}$.

Di Indonesia kesehatan jiwa masih belum menjadi agenda prioritas. Masih rendahnya investasi pemerintah di bidang kesehatan dan kesadaran masyarakat akan kesehatan jiwa dan pemberdayaan masyarakat belum adekuat. Padahal adanya otonomi daerah memungkinkan pemerintah daerah untuk meningkatkan status kesehatan jiwa di wilayahnya baik di wilayah pedesaan dan pedalaman, dimana masyarakat masih umum memasung anggota keluarganya yang menderita gangguan jiwa.

Saat ini, pasung masih menjadi bentuk diskriminasi pada orang dengan gangguan jiwa, dan bahkan hal tersebut telah menjadi "tradisi" memasung bagi klien gangguan jiwa ${ }^{3}$. Pentingnya dukungan dan pendamping dimulai dari keluarga untuk menekan seminimal mungkin dan mengembalikan keberfungsian sosialnya. Keluarga dapat menunjukkannya dengan dukungan baik moril maupun materill emosional, materi, nasehat, informasi, dan penilaian positif papada orang dengan gangguan jiwa dirumah ${ }^{4}$. Pendampingan keluarga merupakan perawatan paling penting dalam penyembuhan klien yang akan berdampak baik secara fisiologis maupun psikologis ${ }^{5,6}$

\section{SUMBER INSPIRASI}

Permasalahan tentang terjadinya pasung di lingkungan RT 02/RW01 Dusun Nangnangan Desa Saronggi Kecamatan Saronggi Kabupaten Sumenep dikarenakan kurangnya peran sistem pendukung dalam memberikan perawatan pada orang dengan gangguan jiwa dalam hal ini dibagi menjadi 3 aspek diantaranya dalah aspek keluarga, aspek masyarakat dan aspek petugas kesehatan. 1). Aspek keluarga. Keluarga masih beranggapan bahwa klien gangguan jiwa merupakan kutukan atau kerasukan roh jahat sehingga dilakukan tindakan pasung untuk mengurangi terjadinya perilaku kekerasan pada pada pasien dan keluarganya mencari solusi kepada tenaga non kesehatan (dukun). Kurangnya pemahaman keluarga tentang cara melakukan pendampingan dan perawatan orang dengan gangguan jiwa. Dan keluarga belum mengenal tanda dan gejala relaps klien gangguan jiwa.2). Aspek Masyarakat. Tindakan pasung pada klien gangguan jiwa telah menjadi "tradisi" dilingkungan Desa Saronggi, dengan alasan keluarga klien malu kepada tetangga dan lingkungan sekitar. Stigma menyebabkan masyarakat tidak berupaya mencari pengobatan dan mendapat pelayanan bermutu rendah, sehingga menyebabkan terjadinya diskriminasi dan risiko kekerasan klien. Kurang memberdayakan klien gangguan jiwa dalam kesehariannya juga menjadi permasalahan tersendiri. 3). Aspek Petugas Kesehatan. Belum terbentuknya kader kesehatan jiwa dilingkungan Desa Saronggi sebagai upaya penanganan langsung kegawat daruratan psikiatrik oleh masyarakat dalam melakukan perawatan orang dengan gangguan jiwa. Belum dilakukannya kontrol yang rutin dan tepat sasaran baik perawatan maupun pengobatan. 
Pendampingan Keluarga Dan Perawatan Orang Dengan Gangguan Jiwa Bebas Pasung

\section{METODE KEGIATAN}

Metode kegiatan berupa penyuluhan dan pelatihan dalam pendampingan keluarga dan perawatan orang dengan gangguan jiwa bebas pasung. Dengan program ini untuk mengurangi terjadinya pemasungan diantaranya:1). Penyuluhan pada keluarga klien serta pihak terkait, 2). Pendampingan cara perawatan orang dengan gangguan jiwa, 3). Pembentukan Kader kesehatan jiwa (Keswa), 4). Penyusunan program kegiatan kader Keswa serta pendampingan dalam melaksanakan program perawatan orang dengan gangguan jiwa, 5). Memfasilitasi sistem rujukan klien Rumah Sakit Jiwa atau Kolaborasi bila diperlukan. Setelah dilakukan kegiatan penyuluhan dan pelatihan dilanjutkan dengan pembentukan kader kesehatan jiwa serta penyusunan dan pendampingan program Keswa diantaranya sesuai dengan Tabel 2.

Tabel 1 Kegiatan Penyuluhan Perawatan Klien Dan Keluarga Gangguan Jiwa Bebas Pasung

\begin{tabular}{lll}
\hline Kegiatan Penyuluh & Respon Peserta & Waktu \\
\hline Pendahuluan & & \\
a. Memberi salam dan Berdoa & a. Menjawab salam & \\
b. Memberi pertanyaan apersepsi & b. Memberi salam & \\
c. Mengkomunikasikan pokok bahasan & c. Menyimak & \\
d. Menjelaskan tujuan & d. Menyimak & \\
\hline Kegiatan Inti & a. Menyimak & 25 mnt \\
a. Memberikan penjelasan tentang gangguan jiwa & b. Bertanya & \\
b. Memberikan kesempatan warga untuk bertanya & c. Memperhatikan & \\
c. Menjawab pertanyaan warga & & \\
\hline Penutup & a. Memperhatikan & \\
a. Menyimpulkan materi penyuluhan bersama keluarga & b. Menjawab & \\
b. Memberikan evaluasi secara lisan & & \\
c. Memberikan salam penutup & & \\
\hline Jumlah & & \\
\hline
\end{tabular}

Tabel 2 Program pembentukan kader Kesehatan Jiwa dalam kegiatan Perawatan Klien Dan Keluarga Gangguan Jiwa Bebas Pasung

\begin{tabular}{ll}
\hline Kegiatan & Tujuan \\
\hline Pembentukan struktur Kader Kesehatan Jiwa & $\begin{array}{l}\text { Untuk mempermudah pengorganisasian kader keswa dalam menjalankan } \\
\text { programnya untuk mencegah terjadinya pasung pada klien gangguan jiwa }\end{array}$ \\
\hline $\begin{array}{l}\text { Menyusun job description pada masing-masing } \\
\text { bidang }\end{array}$ & $\begin{array}{l}\text { Menjalankan program kesehatan jiwa berdasarkan tugas masing-masing } \\
\text { bidang }\end{array}$ \\
\hline $\begin{array}{l}\text { Pembekalan penanganan Kegawat daruratan } \\
\text { Psikiatrik pada klien gangguan jiwa }\end{array}$ & $\begin{array}{l}\text { Pelatihan yang berikan untuk memudahkan kader keswa menangani } \\
\text { kekambuhan klien gangguan jiwa di masyarakat }\end{array}$ \\
\hline $\begin{array}{l}\text { Pendampingan pelayanan kesehatan jiwa di keuarga } \\
\text { dan masyarakat }\end{array}$ & $\begin{array}{l}\text { Mengoptimalkan dan mengurangi stigma pada klien gangguan jiwa di } \\
\text { masyarakat }\end{array}$ \\
\hline $\begin{array}{l}\text { Menentukan rencana tindak lanjut program } \\
\text { kesehatan jiwa }\end{array}$ & Memberdayakan masyarakat untuk kesehatan jiwa di masyarakat \\
\hline
\end{tabular}

\section{IV.KARYA UTAMA}

Berdasarkan hasil kegiatan penyuluhan pada keluarga klien, tokoh masyarakat dan tokoh agama di RT 02/RW01 Dusun Nangnangan Desa Saronggi Kecamatan Saronggi berdampak baik khususnya bagi masyarakat atau keluarga yang mempunyai pasien gangguan jiwa yang mengalami pasung, dimana keluarga dapat mengetahui gejala awal munculnya masalah kejiwaan pada anggota keluarganya.Masyarakat maupun keluarga yang mempunyai anggota keluarga memiliki gangguan jiwa dibutuhkan untuk mengetahui gejala awal dan penangannyan. Orang dengan gangguan jiwa berat masih banyak yang belum mendapatkan penanganan baik secara medis bahkan ada pula pasien yang drop out. Hal ini disebabkan oleh beberapa faktor diantaranya ketidakmampuan dalam pembiayaan dan pengetahuan masyarakat yang masih kurang.Hal tersebut menyebabkan jumlah orang dengan ganggua jiwa masih yang dipasung oleh anggota keluarganya, dengan tujuan tidak mencederai dirinya atau menyakiti orang lain di sekitarnya. Berdasarkan data pada penelitian Wardhani, dkk (2011) dan Tyas (2008) menunjukkan bahwa pemasungan penderita gangguan jiwa lebih banyak dilakukan oleh keluarga 
sebagai pilihan untuk penanganan gangguan jiwa, setelah segala upaya pengobatan medis ${ }^{3}$.

Namun kurangnya pengetahuan keluarga tentang deteksi dini dan penanganan setelah pengobatan di Rumah Sakit Jiwa menyebabkan pasien tidak mendapatkan perawatan di rumah dengan optimal. Pemasungan menjadi salah satu pilihan keluarga dengan tujuan mencegah orang dengan gangguan jiwa berat melukai diri sendir ataupun orang di sekitarnya. Kemudahan dalam melakukan pengawasan pada orang dengan gangguan jiwa menjadi alasan keluarga untuk melakukan pasung terhadap anggota keluarga yang menderita gangguan jiwa. Ketidaktersediaan akses tentang keberlanjutan dari proses penyembuhan dan pengobatan rutin di pedesaan menyebabkan keluarga yang memiliki anggota keluarga dengan gangguan jiwa berat melakukan pasung. Awal gejala yang muncul pada orang dengan gangguan jiwa yang tidak diketahui menyebabkan keterlambatan tatalaksana orang dengan gangguan jiwa. Keterlambatan penanganan juga diakibatkan oleh stigma terhadap orang dengan gangguan jiwa, sehingga keluarga akan menolak apabila ada anggota keluarga yang diketahui memiliki gejala gangguan jiwa. Sehingga prognosis orang dengan gangguan jiwa akan semakin buruk sudah dianggap mengganggu serta membahayakan diri dan lingkungan sekitarnya maka akan dengan sangat terpaksa dilakukan pemasungan.

\section{ULASAN KARYA}

Peran serta mitra dalam kegiatan Pengabdian Kepada Masyarakat cukup aktif di buktikan sejak awal persiapan kegiatan mulai dari penyuluhan, pembentukan kader Keswa serta pendampingan dan sosialisasi kepada keluarga dan pasien ganggaun jiwa diikuti dengan baik dan kompak. Tokoh masyarakat dan tokoh agama menyambut baik adanya kader Keswa di RT 02/RW01 Dusun Nangnangan Desa Saronggi Kecamatan Saronggi.
Sebagian besar keluarga pasien gangguan jiwa mempunyai latar belakan pendidikan Sekolah Dasar, sehingga membutuhkan waktu yang lama dan komunikasi yang lengkap dan terperinci untuk meningkatkan pengetahuan keluarga dalam penanganan pasien gangguan jiwa, serta sebagian besar keluarga pasien dari kalanagn pendapatan ekonomi ke bawah, sehingga banyaknya keluarga tidak memeriksakan keluarganya(Pasien) ke pelayanan kesehatan terdekat.

\section{KESIMPULAN}

Kegiatan Pengabdian Kepada Masyarakat yang diawali dengan penyuluhan pada keluarga klien, tokoh masyarakat dan tokoh agama dapat diikuti dengan baik dan respon peserta sangat antusias serta terdapat respon balik dari peserta sehingga pengetahuan peserta tentang penanganan awal gejala pasien gangguan jiwa dapat diaplikasikan.Pembentukan Kader Kesehatan Jiwa oleh Tim PKM Unija dapat berjalan dengan lancar, dan telah terbentuk pengurus Kader Kesehatan Jiwa (KESWA) di RT 02/RW01 Dusun Nangnangan Desa Saronggi Kecamatan Saronggi, dan dapat di lakukan pembuatan program Keswa di lingkungan tersebut.Sosialisasi dan pendampingan pelayanan kesehatan jiwa dilakukan dengan kunjungan rumah oleh Tim PKM UNIJA dengan kader Keswa serta melakukan sosialisasi cara penanganan pasien dengan pasung.

\section{DAMPAK DAN MANFAAT KEGIATAN}

Dampak dan manfaat kegiatan antara lain meningkatkan pengetahuan dan perilaku keluarga klien dalam melakukan pendampingan dan perawatan orang dengan gangguan jiwa, memberikan pemahaman dan informasi yang akurat pada keluarga dan masyarakat dalam mencari solusi pengobatan yang tepat sehingga mengubah "tradisi" tindakan pasung yang terjadi pada orang dengan gangguan jiwa, keluarga yang mempunyai anggota 
Pendampingan Keluarga Dan Perawatan Orang Dengan Gangguan Jiwa Bebas Pasung

keluarga orang dengan gangguan jiwa mampu melaksanakan perawatan mandiri pada klien gangguan jiwa dengan tepat dan tidak terjadi tindakan pasung pada klien.

\section{DAFTAR PUSTAKA}

1. Kurniawan, Y., \& Sulistyarini, I. "Komunitas SEHATI (Sehat Jiwa dan Hati) sebagai Intervensi Kesehatan Mental Berbasis Masyarakat". INSAN Jurnal Psikologi dan Kesehatan Mental, I(2).(2016):112-124.

2. Badan Penelitian dan Pengembangan Kesehatan. “Riset Kesehatan Dasar”. Jakarta: Kementerian Kesehatan RI.2013.

3. Lestari, W., \& Wardhani, F."Stigma dan Penanganan Penderita Gangguan Jiwa Berat yang Dipasung". Buletin Penelitian Sistem Kesehatan, 17(2), (2014): 157-166.

4. Hendriyana, A."Setiap Tahun Penderita Gangguan Jiwa di Indonesia Terus Meningkat”. http://www.unpad.ac.id/profil/dr-suryani-skpmhscsetiap-tahun-penderita-gangguan-jiwa-diIndonesia-terus-meniningkat/ . 2013. Diakses 2 Agustus 2017

5. Keliat, B. A."Peran Serta Keluarga dalam Keperawatan Klien Gangguan Jiwa”. Jakarta: Depkes RI.2002.

6. Notoatmodjo, S."Kesehatan Masyarakat, Ilmu dan Seni”. Jakarta: PT. Rineka Cipta.2007. 